\title{
Assessment of Nitrate in Wells and Springs in the North Central Ethiopian Highlands
}

\author{
Adugnaw T. Akale ${ }^{1}$ (D), Mamaru A. Moges ${ }^{1,2}$, Dessalegn C. Dagnew ${ }^{1,3}$ (D), Seifu A. Tilahun ${ }^{1,2}$ (iD) \\ and Tammo S. Steenhuis $1,2,4, *$ (D) \\ 1 Faculty of Civil and Water Resources Engineering, Bahir Dar Institute of Technology, Bahir Dar University, \\ P.O. Box 26, Bahir Dar, Ethiopia; adugnawtadesse@gmail.com (A.T.A.); mamarumoges@gmail.com (M.A.M.); \\ cdessalegn@yahoo.com (D.C.D.); satadm86@gmail.com (S.A.T.) \\ 2 Blue Nile Water Institute, Bahir Dar University, P.O. Box 79, Bahir Dar, Ethiopia \\ 3 Institute of Disaster Risk Management and Food Security Studies, Bahir Dar University, P.O. Box 5501, \\ Bahir Dar, Ethiopia \\ 4 Department of Biological and Environmental Engineering, Cornell University, Ithaca, NY 14853, USA \\ * Correspondence: tss1@cornell.edu; Tel.: +1-607-255-2489
}

Received: 22 February 2018; Accepted: 4 April 2018; Published: 13 April 2018

\begin{abstract}
Under the auspices of the UN Millennium Development Goals, access to safe drinking water in the developing world, including the Ethiopian highlands, has improved greatly. However, in many cases, it is not known how safe the water is. With the intensification of agriculture and increasing applications of fertilizers, high levels of nitrate are a concern. The objective of this study is to assess the nitrate levels in drinking water supply systems. To assess nitrate levels, we sampled 213 water supply points in a $4880 \mathrm{~km}^{2}$ area in the northwest Ethiopian highlands. The results show that the average concentration was below the World Health Organization (WHO) health standard of $10 \mathrm{mg} \mathrm{N}-\mathrm{NO}_{3} / \mathrm{L}$. The average concentration in wells was $3.3 \mathrm{mg} \mathrm{N}-\mathrm{NO}_{3} / \mathrm{L}$ and in springs was $1.8 \mathrm{mg} \mathrm{N}-\mathrm{NO}_{3} / \mathrm{L}$. Only in three wells, that were in agricultural cropped areas, was the WHO standard exceeded. Wells in the agricultural fields had an average nitrate concentration of $3.6 \mathrm{mg} \mathrm{N}-\mathrm{NO}_{3} / \mathrm{L}$, which was almost twice that on grazing land and four times that in upland wells. Spatially, the groundwater nitrate concentrations were greater in the moderately sloped parts of the study area where agriculture was intensive and denitrification limited. Thus, although current nitrate levels are safe, in the future, the nitrate concentration could exceed the WHO health standard when fertilizer use increases.
\end{abstract}

Keywords: Ethiopian highlands; Africa; Sub-Saharan; potable water; drinking water; nitrate; water quality; groundwater; United Nations

\section{Introduction}

Since safe and reliable drinking water is essential for economic vitality and public health [1], goal 6.1 of the United Nations Millennium Development Goals to "achieve universal and equitable access to safe and affordable drinking water for all by 2030" has been included in the United Nations Inter-Agency and Expert Group on Sustainable Development Goals (SDG) Indicators. Progress is being made but verification is cumbersome due to a lack of data.

Investigations in developing countries on safe drinking water are mainly focused on the incidence of acute infectious diarrhea [1] because it is a cause of death among young children. In addition, chemical agents have been associated with adverse health effects [2-5]. One of these chemicals of concern is nitrate [6,7]. Risks to human health associated with high levels of nitrate in drinking water include thyroid gland dysfunction, gastric cancer, and decrease in the capacity of blood to transport oxygen (known as methemoglobinemia) in infants below six months old [8-10]. In addition, it poses 
health problems for pregnant women [11]. Finally, excessive nitrates can cause health problems in ruminant animals and once released into the environment, can cause dead zones in the oceans near major rivers [12-17].

Groundwater is preferred as a source of potable water because it is available throughout the year and is less contaminated than surface water [18]. However, according to studies in both developed and developing countries, nitrate levels in groundwater have been increasing [19] and can present serious problems [6,20-26]. In the northeast of Spain, 80\% of the groundwater nitrate concentration exceeded $5.6 \mathrm{mg} / \mathrm{L}$ due to use of nitrogen-based fertilizers, and animal and human wastes [27]. In the North China plain, $50 \%$ of sampled wells exceeded the limit of $10 \mathrm{mg} \mathrm{N}-\mathrm{NO}_{3} / \mathrm{L}$ concentration due to application of untreated wastewater and excessive fertilizer on agricultural fields [7,20]. Studies in developed countries such as UK found high nitrate concentrations related to intensive agriculture and high-density cattle and pig farms. Nitrate levels ranged from 4.5 to $11.3 \mathrm{mg} \mathrm{N}-\mathrm{NO}_{3} / \mathrm{L}$ in groundwater and were more than $22 \mathrm{mg} \mathrm{N}-\mathrm{NO}_{3} / \mathrm{L}$ in surface water in the winter [28-30].

In developing countries, little is known about the impact of agriculture on water quality. Studies in Ghana reported nitrate concentrations reaching 9-10 mg/L in irrigation wells located close to intensively cultivated irrigated fields [31]. Similar studies in India and parts of Africa indicated that $20-50 \%$ of the groundwater wells exceed the $10 \mathrm{mg} / \mathrm{L}$ nitrate level limit [32]. A rapid assessment of drinking water quality in Ethiopia showed that 32\% of the wells were contaminated with nitrate [33]. A study on the Kebean and Akakie rivers of Addis Ababa, Ethiopia found poor quality surface and groundwater due to improper waste management, agricultural activities, poor sanitation, and low levels of hygiene [34]. Research in the Ginchi watershed in southern Ethiopia found that there is pollution of surface water due to human and animal feces, agricultural activities, and a lack of waste disposal systems [35]. Finally, groundwater quality monitoring results in the Ethiopian highlands agricultural watersheds indicated that nitrate levels are rising during the rainy season [36].

Greater amounts of fertilizer are applied on farms because of both the loss of organic matter in the degrading soil base and the need to produce more food for a rapidly increasing population [37,38]. Despite the greater application of fertilizers, the quality of surficial groundwater-which is used as the source of drinking water in the Ethiopia highlands-has not been well documented. The objective of this study is, therefore, to assess nitrate concentrations in the surficial groundwater. The South Gondar Zone in northern Ethiopia was selected as our study area because of widespread use of groundwater as a water supply, intensifying agriculture with increasing fertilizer use, and plenty of rainfall to leach the nitrate to the groundwater.

\section{Materials and Methods}

\subsection{The Study Area}

The study was conducted in the Farta, Estie, Dera, and Andabit woredas (districts) in the South Gondar Zone (province) of the Ethiopian highlands, which is located $700 \mathrm{~km}$ north of Addis Ababa (Figure 1). The selected study area covers $4880 \mathrm{~km}^{2}$ and is characterized by rugged topography with steep slopes on the eastern and southern borders, deep gorges in the southeast, moderate slopes in the center, and a plain near Lake Tana in the west. Elevations are $4063 \mathrm{~m}$ near Guna Mountain and $1294 \mathrm{~m}$ in the southeastern part near the deep Blue Nile gorge (Figure 1). Mean annual rainfall was $1518 \mathrm{~mm}$ from 2010 to 2015.

According to land use classification, $45 \%$ of the land is cultivated; $26 \%$ has a cover of forests, shrub, and bush; $19 \%$ is grass lands; and the remaining $10 \%$ is water and built-up areas [39]. Grasslands are mainly found in the periodically saturated valley bottom lands and located close to waterways. Croplands are generally at the midslope positions, whereas forest, shrubs, and bush lands are on the steep slope areas with shallow soils.

Land use varies consistently with topographic position in South Gondar. We distinguished bottom, midslope, and upslope landscape units (Figure S1). The valley bottoms have slopes between 
0 and 5 degrees, close to shallow waterways, and are located at elevations ranging from 1449 to $3349 \mathrm{~m}$. Midslope areas are situated on hillsides with slopes ranging from 3 to 16 degrees, are not close to the stream network, and are found at elevations starting at $2043 \mathrm{~m}$ and ending around $3509 \mathrm{~m}$. Finally, upslope areas on the steepest hillsides have slopes ranging from 10 to 30 degrees and begin at elevations of $2244 \mathrm{~m}$ (Table 1).

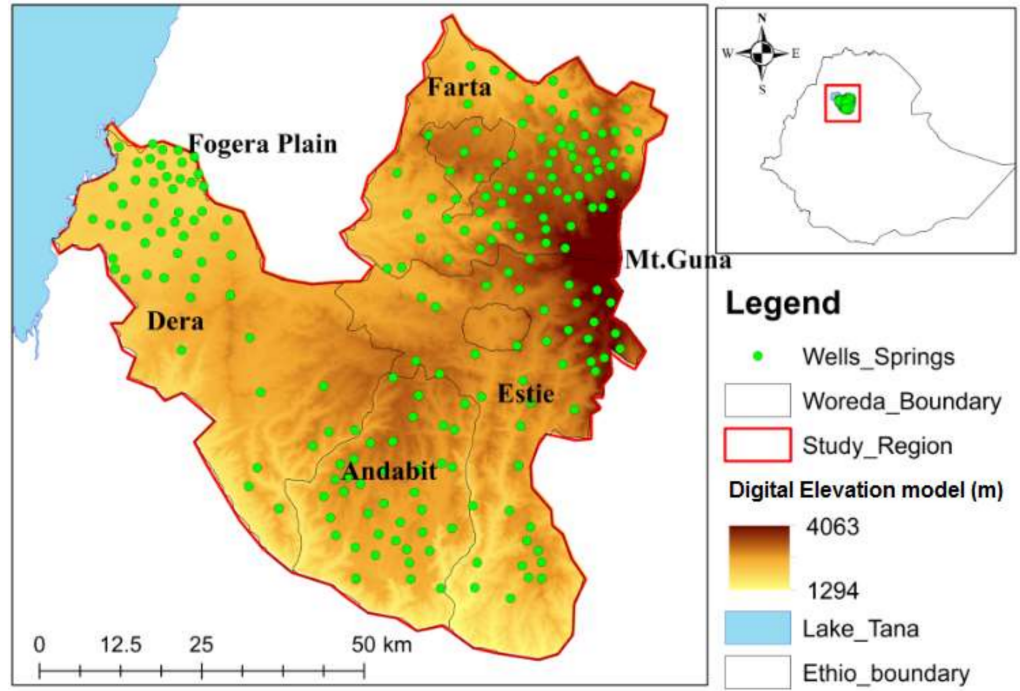

Figure 1. Location of the study area within Ethiopia and the topographic map of the study area with springs and wells.

Table 1. The slope and elevation of the landscape units at various topographic positions in South Gondar.

\begin{tabular}{cccc}
\hline Topography & Range of Slope (degree) & Range of Elevation $(\mathbf{m})$ & Median Elevation $(\mathbf{m})$ \\
\hline Valley bottom & $0-5$ & $1449-3349$ & 2217 \\
Midslope & $3-16$ & $2043-3509$ & 2581 \\
Upslope & $10-30$ & $2244-3659$ & 2653 \\
\hline
\end{tabular}

The hydrology is typical for a mountainous degraded landscape with a permeable surface layer overlaying a slowly permeable layer that is recently formed [40]. The valley bottoms become fully saturated after approximately $500 \mathrm{~mm}$ of cumulative rainfall by interflow from the hillsides and precipitation. Some of the most degraded land form a perched water table and, together with the periodically saturated valley bottoms, generate surface runoff [40].

Rain-fed agriculture is practiced during the rain phase from May until September [41]. Urea containing $46 \%$ ammonia nitrogen, diammonium phosphate with a composition of $20 \% \mathrm{~N}$ and $50 \% \mathrm{P}_{2} \mathrm{O}_{5}$, and ash were applied in modest amounts (Table 2). According to the local agricultural agents, nitrate application varied from $22 \mathrm{~kg} \mathrm{~N} \mathrm{ha}^{-1}$ in Farta to $35 \mathrm{~kg} \mathrm{~N} \mathrm{ha}^{-1}$ in Andabit and Dera (Table 2).

Table 2. Fertilizer use and amount of fertilizer applied in four woredas in South Gondar, Ethiopia.

\begin{tabular}{|c|c|c|c|c|c|c|c|}
\hline Woreda & $\begin{array}{c}\text { Total Area } \\
\left(\mathrm{km}^{2}\right)\end{array}$ & $\begin{array}{c}\text { Cropland } \\
\left(\mathrm{km}^{2}\right)\end{array}$ & $\begin{array}{c}\text { Cropland } \\
\text { Coverage }(\%)\end{array}$ & $\begin{array}{c}\text { Urea } \\
\left(\mathrm{kg} \mathrm{ha}^{-1}\right)\end{array}$ & $\begin{array}{c}\text { Diammonium } \\
\text { Phosphate } \\
\left(\mathrm{kg} \mathrm{ha}^{-1}\right)\end{array}$ & $\begin{array}{c}\text { Fertilizer N } \\
\text { Applied (Gg) }\end{array}$ & $\begin{array}{c}\text { Fertilizer N } \\
\text { Applied } \\
\left(\mathrm{kgN} \mathrm{ha}{ }^{-1}\right)\end{array}$ \\
\hline Farta & 1251 & 652 & $52 \%$ & 34 & 34 & 1.43 & 22 \\
\hline Estie & 1354 & 594 & $44 \%$ & 39 & 39 & 1.49 & 25 \\
\hline Andabit & 794 & 318 & $40 \%$ & 55 & 55 & 1.11 & 35 \\
\hline Dera & 1478 & 625 & $42 \%$ & 54 & 54 & 2.19 & 35 \\
\hline Average & 1220 & 547 & $45 \%$ & 45 & 45 & 1.59 & 29 \\
\hline
\end{tabular}




\subsection{Data Collection and Analytical Methods}

The cross-sectional study (i.e., one sample per waterpoint) was conducted to assess the nitrate concentration in drinking water supply points from December 2013 to June 2014 (Table S1). Samples were collected from protected springs and hand-dug wells during the dry phase when the temporal variation was less than during the rain phase when fertilizers were applied. A total of 213 rural water supply schemes were randomly selected from the functional wells in the four woredas: $190(89 \%)$ were wells and the remaining $23(11 \%)$ were protected springs. The main land use of the recharge contributing area and topographic position (upslope, midslope, and bottom slope) were noted for each drinking water point (Table 3). Most waterpoints were located in the valley bottoms and midslopes where most people live. The recharge area for the majority of wells and springs was in agriculture because it was the dominant land use (Table 3).

Table 3. Landscape position and land use of recharge areas contributing to the springs and wells.

\begin{tabular}{ccccc}
\hline Land Use & Valley Bottom & Midslope & Upslope & Total \\
\hline Agriculture & 68 & 44 & 13 & 125 \\
Grass & 34 & 28 & 0 & 62 \\
Forest & 0 & 18 & 8 & 26 \\
Total & 102 & 90 & 21 & 213 \\
\hline
\end{tabular}

Water samples $(100 \mathrm{~mL})$ for nitrate analysis were taken from wells and springs after 4 min of pumping or flushing of faucets. Samples were analyzed for nitrate in the field using a Plain Test 7100 Spectrophotometer with a detection limit of $0.001 \mathrm{mg} / \mathrm{L}$ [36]. The test was conducted in a special Nitratest tube. This is a graduated sample container with a hopper bottom to facilitate settlement and decanting of the sample. The reduction to nitrite with sulphanilic acid forms a red color in the presence of $\mathrm{N}$-(1-naphthyl)-ethylene. The two reagents are provided in a single nitricol tablet. The intensity of the red color is proportional to the nitrate concentration and is measured using a Palintest Photometer.

The nitrate concentrations were compared with the WHO maximum permissible limit and natural background concentration without human influences. The WHO upper limit in drinking water is $10 \mathrm{mg} \mathrm{N}-\mathrm{NO}_{3} / \mathrm{L}$ [1]. Natural nitrate background levels in the United States were found to be $3 \mathrm{mg}$ $\mathrm{N}-\mathrm{NO}_{3} / \mathrm{L}$ [42].

\subsection{Statistical Analysis}

The one-way analysis of variance (ANOVA) statistical test was used to determine whether a statistically significant difference of nitrate concentration existed between the land uses and the topographic landscape positions. A $p$-value less than 0.05 was considered to show a statistically significant difference.

A map of the spatial distribution of nitrate concentration was developed in ARC GIS 10.4.1 using the inverse distance method.

\section{Results and Discussion}

\subsection{Overview of Nitrate Concentration in South Gondar}

\subsubsection{Springs versus Wells}

The average nitrate concentration in samples from the 190 wells was $3.3 \mathrm{mg} \mathrm{N}-\mathrm{NO}_{3} / \mathrm{L}$ and significantly greater than the average in the 23 springs, which was $1.4 \mathrm{mg} \mathrm{N}-\mathrm{NO}_{3} / \mathrm{L}$ (Table 4 ). The maximum nitrate concentrations were $15.8 \mathrm{mg} \mathrm{N}-\mathrm{NO}_{3} / \mathrm{L}$ in the wells and $3.7 \mathrm{mg} \mathrm{N}-\mathrm{NO}_{3} / \mathrm{L}$ in the springs (Figure 2a). The $\mathrm{N}-\mathrm{NO}_{3}$ concentrations in springs were smaller because they were found in places where groundwater intersects with the organic-rich surface and can become anoxic [43], promoting denitrification [44,45]. Water from wells was obtained (by pump) from deeper depths and 
has typically sufficient oxygen to limit denitrification. Note, however, that the low nitrate concentration in springs was not an indication that other constituents (such as microbial contamination) were also low as there is a greater likelihood of contamination from surface sources in springs than wells [43].

Table 4. Groundwater nitrate concentration based on land use, topographic position and water sources, and ANOVA analysis results.

\begin{tabular}{|c|c|c|c|c|c|c|c|}
\hline \multirow[t]{2}{*}{ Categories } & \multirow{2}{*}{\multicolumn{2}{|c|}{ Total Sampled }} & \multirow{2}{*}{$\%$ of Total } & \multicolumn{3}{|c|}{$\begin{array}{c}\text { Nitrate Concentration } \\
\mathrm{mg} \mathrm{N}-\mathrm{NO}_{3} / \mathrm{L}\end{array}$} & \multirow[t]{2}{*}{ ANOVA $p$-Value } \\
\hline & & & & Average & Max & Min & \\
\hline \multirow{3}{*}{ Land use } & Agriculture & 125 & 59 & $3.6 \pm 2.4$ & 15.8 & 0.1 & \multirow{3}{*}{0.001} \\
\hline & Forest & 26 & 12 & $2.2 \pm 0.9$ & 3.5 & 0 & \\
\hline & Grass & 62 & 29 & $2.3 \pm 0.5$ & 3.1 & 0.4 & \\
\hline \multirow{3}{*}{ Slope position } & Upper & 21 & 10 & $0.9 \pm 1$ & 3.5 & 0 & \multirow{3}{*}{0.000} \\
\hline & Mid & 90 & 42 & $3.7 \pm 2.3$ & 15.8 & 0.4 & \\
\hline & Bottom & 102 & 48 & $2.9 \pm 1.3$ & 9.2 & 0.8 & \\
\hline \multirow{3}{*}{ Water supply } & Well & 190 & 89 & $3.2 \pm 2$ & 15.8 & 0.1 & \multirow[b]{2}{*}{0.003} \\
\hline & Spring & 23 & 11 & $1.4 \pm 1$ & 3.7 & 0 & \\
\hline & Total & 213 & & & & & \\
\hline
\end{tabular}

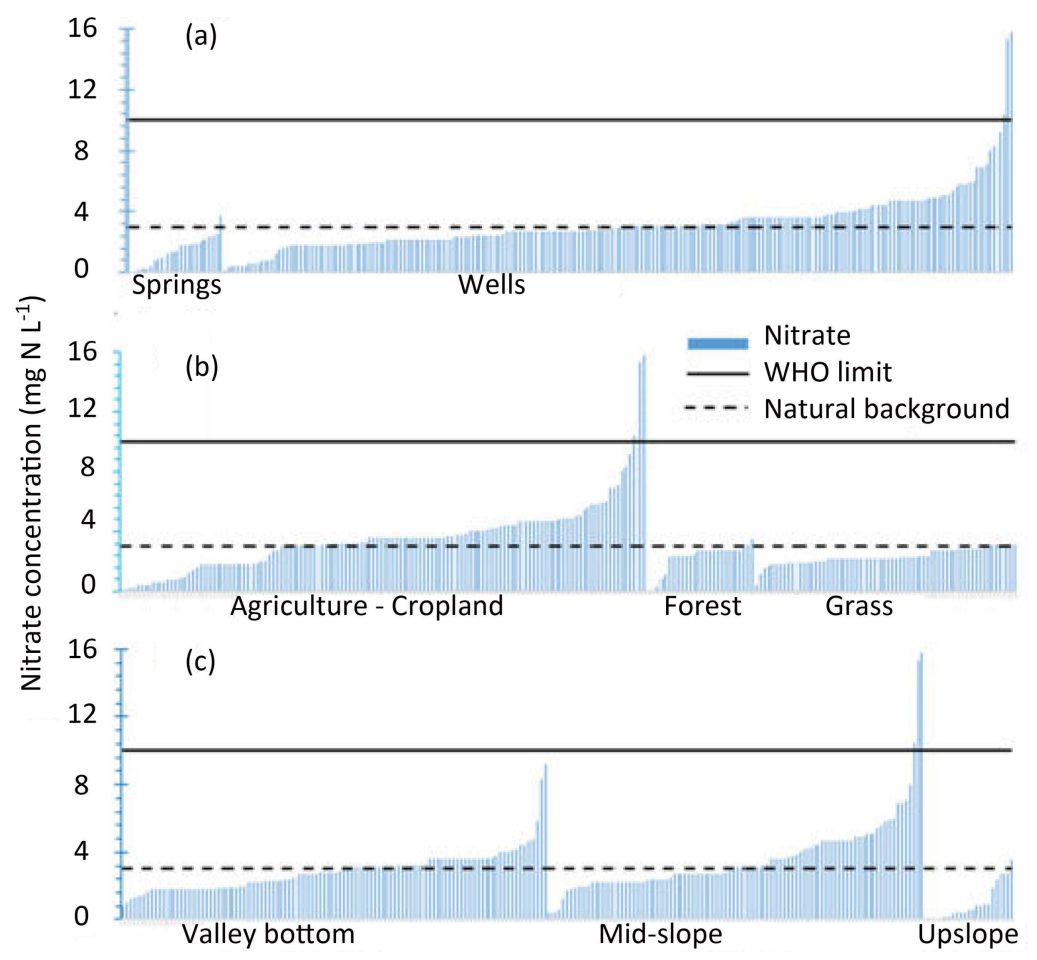

Figure 2. Nitrate concentration in South Gondar Zone sampled in the period from December 2013 to June 2014: (a) in springs and wells; (b) upstream land use; and (c) topographic position. The solid lines indicate the $10 \mathrm{mg} / \mathrm{L}$ WHO standard and the $3.4 \mathrm{mg} / \mathrm{L}$ natural background.

\subsubsection{Land Use Effects}

The average nitrate concentration in groundwater in the cropped agricultural areas was $3.6 \mathrm{mg}$ $\mathrm{N}-\mathrm{NO}_{3} / \mathrm{L}$ while the maximum nitrate concentration in areas with mainly grass and forest was less than that (3.1 $\mathrm{mg} \mathrm{N}-\mathrm{NO}_{3} / \mathrm{L}$ for grasslands and $3.5 \mathrm{mg} \mathrm{N}-\mathrm{NO}_{3} / \mathrm{L}$ for forests; Table 4, Figure 2b and Figure S1). The statistically greater nitrate concentration under the agricultural land (Figure $2 \mathrm{~b}$ and Figure S1, Table 4) originates from the modest application of nitrogen fertilizers (Table 2) that are easily leached in the form of nitrate to the groundwater with high rainfall of over $1200 \mathrm{~mm}$ in the growing period [46]. 
Our results are similar to those of observations in Ethiopian highlands and the USA [36,47] where nitrate concentrations in the agricultural watersheds are greater than in forested watersheds. However, the observed concentrations in our area were less than those reported in the regions where fertilizer application was in the order of $100 \mathrm{~kg} \mathrm{~N} \mathrm{ha}^{-1}$ or more in many cases [20,45-47].

\subsubsection{Topographic Position}

Nitrate concentrations were greater midslope than both upslope and downslope in the valley bottom (Figure 2c and Figure S1, Table 4). The average nitrate concentration at midslope, where most of the agricultural crops (including potatoes) are grown, was $3.7 \mathrm{mg} \mathrm{N}-\mathrm{NO}_{3} / \mathrm{L}$. This is almost four times that of the upslope areas with mostly brush and forest and minor cultivation of crops due to the steepness of the land, shallow soils, and frost (for the highest elevation above $3400 \mathrm{~m}$ ). Despite the contribution of interflow with high nitrate concentrations [48], the nitrate concentrations in water supply points in the periodically saturated valley bottoms were less than at midslope. This can be explained by the denitrification of nitrate when soils become saturated, from plant uptake by grasses, and by collecting manure from grazing animals for fuel (Figure 2b and Figure S1, Table 4).

There is an intricate relationship between landscape position and land use. Crop production on the steep lands and shallow soils at higher elevations is not profitable and is therefore not cultivated and is instead covered with forests or brush. These upslope lands with natural vegetation minimally affected by grazing are located above the cropped areas and have low input of fertilizers; therefore, they have good quality groundwater with an average nitrate concentration of $2.3 \mathrm{mg} \mathrm{N}-\mathrm{NO}_{3} / \mathrm{L}$ (Table 4). The valley bottoms become saturated during the monsoon rain phase [48] and are therefore unsuitable for crop production. Because grass tolerates wet conditions, valley bottoms have become the communal grazing lands. Although the nitrate concentrations are low in the valley bottom lands, bacterial contaminations from manure from grazing animals usually make it an undesirable source of drinking water $[49,50]$.

\subsubsection{Fertilizer Application Rate}

The fertilizer rate and the amount of cropped agricultural land varies between the four woredas (Table 2). Nitrate concentrations in wells and springs that derive water from catchments with crop land are ranked for each woreda in Figure 3. The Dera and the Farta woredas have the largest number of wells that are at or below the natural background nitrate concentration (Figure 3).

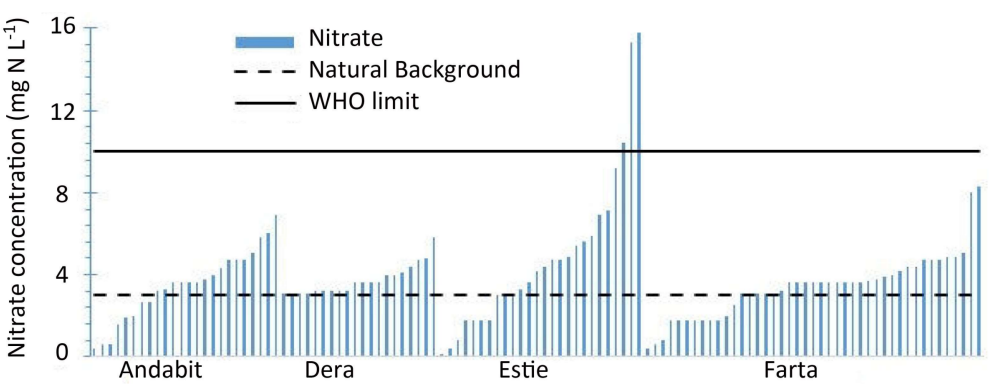

Figure 3. Nitrate concentration in wells and springs in the agricultural lands of Andabit, Dera, Estie, and Farta woredas in South Gondar, Ethiopia.

The Dera watersheds, in which the Fogera Plain with intensive crop agriculture is located, has the highest use of fertilizer on area-wide and per ha bases (Table 2). Despite this, it has the lowest nitrate concentration due to the high groundwater table during the rain phase enhancing denitrification of the nitrate leached.

The Farta woreda, in the northern part of the study area (Figure 1), had the highest density of agricultural land (52\%, Table 2), but farmers applied the lowest rate of fertilizers. This explains the fact 
that, in the absence of denitrification, there were only relatively few concentrations in the wells and springs in the agricultural land above the natural background nitrate level in Figure 3.

Water points in the Estie and Andabit woredas had the most wells with concentrations above the natural background. The rolling topography and the best agricultural soils in Estie woreda (in the center the study area, Figure 1) facilitate the cultivation of various crops such as potatoes, teff, and barley. Of all crops, potatoes receive the greatest amount of fertilizer. Two of the three wells with concentration above $10 \mathrm{mg} \mathrm{N}-\mathrm{NO}_{3} / \mathrm{L}$ were located downstream of potato fields. The third well with nitrate in excess of the WHO standard was affected by a compost pile.

The Andabit woreda (located near the Blue Nile gorge in the south, Figure 1) had the highest rate of fertilizer applied per ha but the area-wide application rates were smaller than in the Estie woreda because the area has steep slopes near the Blue Nile gorge with deep gullies and wide, flat lands near the stream. Nitrate concentrations were therefore not as high due to dilution of low-nitrate water from nonagricultural areas.

\subsection{Mapping Nitrate Concentrations}

The nitrate concentration in the groundwater (depicted in Figure 4) is in accordance with results presented above. The nitrate concentrations below $3 \mathrm{mg} \mathrm{N}-\mathrm{NO}_{3} / \mathrm{L}$ (dark green) were found at the highest elevations with steep slopes and shallow soils near Mount Guna and in the southern portion of the study area covered with forests and brush. In addition, nitrate concentrations were low in the areas with grass cover in the north-central and northwest part of the study area (compare Figures 4 and 5). Finally, the nitrate concentrations were less than $3 \mathrm{mg} \mathrm{N}-\mathrm{NO}_{3} / \mathrm{L}$ in the Fogera Plain near Lake Tana; this area has intensive agriculture and is also periodically saturated. Therefore, nitrate that is leached when the groundwater is low is denitrified when it is close to the surface and organic matter is present $[45,50]$. Beside the Fogera Plain, most intensive agriculture is practiced on the moderately sloping and relatively flat areas located in the central part of the study area in the Estie woreda and along the southeastern boundary in the Andabit woreda (Figures 4 and 5). These areas are relatively well drained and have nitrate concentrations in the groundwater of over $5 \mathrm{mg} \mathrm{N}-\mathrm{NO}_{3} / \mathrm{L}$ (yellow and red colors in Figure 3).

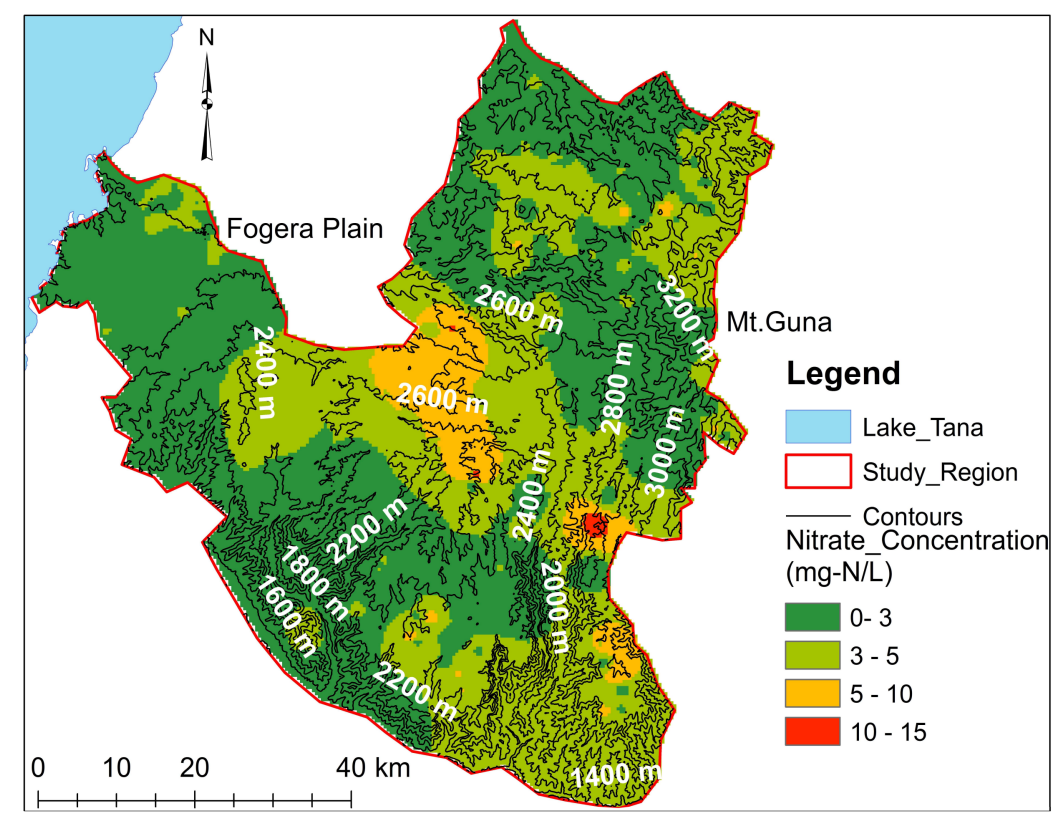

Figure 4. Topographic map (Black line denotes the elevation contours white color fonts denotes elevation contour) and the spatial distribution of nitrate concentrations in the study area in the Ethiopian highlands from wells and springs sampled from December 2013 to June 2014. 


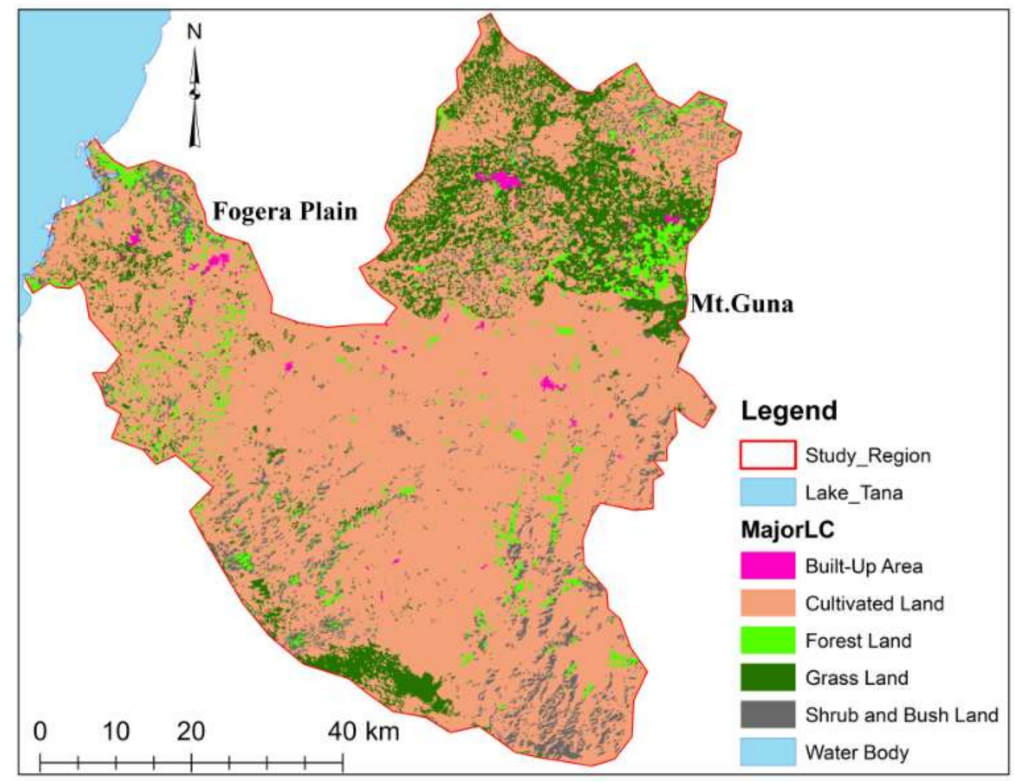

Figure 5. Land use map of study area.

In general, nitrate concentrations in the drinking water are currently not worrisome. Fifty-five percent of the area had nitrate concentrations below the natural nitrate background concentrations in the USA of $3 \mathrm{mg} \mathrm{N}-\mathrm{NO}_{3} / \mathrm{L}$ [42]. Likely, it will not stay that low in the future because fertilizer use is increasing from the current use (on average, $29 \mathrm{~kg} \mathrm{~N} \mathrm{ha}^{-1}$ year $^{-1}$, Table 2). When fertilizer use in the Ethiopian highlands approaches that in developed countries, we expect to find similar concentrations over the WHO standard [12,24-27], especially since the precipitation is much higher than in the temperate regions, promoting leaching of the applied nitrogen before the plant can take it up. In our study site, we already found concentrations above the WHO standard where potatoes, that were fertilized at a greater rate than other field crops, were grown. In addition, we confirmed the impact of fertilizers in a related study [36] where we found that nitrate concentrations were elevated shortly after fertilizers were applied.

Thus, although a large portion of the population will have access to drinking water under the goals set by UNESCO, at the same time, pollution is increasingly making it unsafe to drink. Consequently, a careful monitoring program is needed to ascertain that the drinking water is safe.

\section{Conclusions}

Nitrate concentrations were assessed in groundwater and the distribution of these concentrations was mapped in four woredas of South Gondar Province in the north-central part of the Ethiopian highlands. The results show that out of the total 213 randomly selected water points, consisting of springs and wells, only three wells had nitrate concentrations that were above the WHO permissible health standard. Nitrate concentrations in well water was almost twice those in spring water. As expected, nitrate concentrations in agricultural land, located mainly at the midslope position of the landscape, had the greatest concentration of groundwater, averaging $3.6 \mathrm{mg} \mathrm{N}-\mathrm{NO}_{3} / \mathrm{L}$. Upslope forest and shrub land had the lowest concentrations.

The mapped spatial distribution of nitrate concentrations shows that the lowest nitrate concentrations were found both in the highly productive Fogera Plain near lake Tana due to denitrification, and in the mountainous and steep areas in the upper parts of the watersheds without agriculture. Intermediate and high nitrate concentrations were found in the central portions of the study area with intermediate slopes and where agriculture was practiced. Since overall fertilizer use is still modest for most crops, with average application rates varying from 22 to $35 \mathrm{~kg}$ of N/ha, and less than can be taken up by the crop, most nitrate concentrations in groundwater for the major crops are 
below the $\mathrm{WHO}$ standard of $10 \mathrm{mg} \mathrm{N}-\mathrm{NO}_{3} / \mathrm{L}$. Two of the three wells with high nitrate concentrations were observed near potato fields with high levels of fertilizer. We expect that nitrate concentrations in drinking water from wells and springs will rise when fertilizer use increases. This will likely be more severe than in temperate climates because of the high rainfall over a four-month period in the (semi)humid climates; this rainfall promotes fast leaching of the nitrate before it can be taken up by the crop.

Supplementary Materials: The following are available online at http:/ / www.mdpi.com/2073-4441/10/4/476/s1. Figure S1: Boxplots of the nitrate concentrations in groundwater measured in developed springs and wells at three hillslope positions and land use in the waterpoint drinking area in South Gondar Zone from December 2013 to June 2014. Table S1: Number of water points sampled each month in the four woredas in South Gondar, Ethiopia.

Acknowledgments: This work was done through the support of CARE Ethiopia North Program Office during data collection and lab analysis. We would like to thank the project team for their time and unwavering support for data compilation, the Borlaug LEAP, and Partnerships for Enhanced Engagement in Research (PEER) of the National Academies of Sciences, Engineering, Medicine of the USA for their financial support, and the first author for the fellowship and research support. Peggy Stevens aided greatly in the final manuscript editing.

Author Contributions: A.T.A., S.A.T., M.A.M. and T.S.S. conceived and designed the experiments; A.T.A. performed the experiments; A.T.A. and D.C.D. analyzed the data; M.A.M. contributed reagents/materials/analysis tools; A.T.A. and T.S.S. wrote the paper with aid of S.A.T., D.C.D. and M.A.M.

Conflicts of Interest: The authors declare no conflict of interest. The sponsors had no role in the design of the study; in the collection, analyses, or interpretation of data; in the writing of the manuscript; or in the decision to publish the results.

\section{References}

1. Hunter, P.R.; MacDonald, A.M.; Carter, R.C. Water Supply and Health. PLoS Med. 2010, 7, e1000361. [CrossRef] [PubMed]

2. $\mathrm{Wu}, \mathrm{J}$.; Sun, Z. Evaluation of shallow ground water contamination and associated human health risk in an alluvial plain impacted by agricultural and industrial activities, midwest China. Expo. Health 2016, 8, 311-329. [CrossRef]

3. Barroso, M.F.; Ramalhosa, M.J.; Olhero, A.; Antão, M.C.; Pina, M.F.; Guimarães, L.; Chaminé, H.I. Assessment of ground water contamination in an agricultural peri-urban area (NW Portugal): An integrated approach. Environ. Earth Sci. 2015, 73, 2881-2894. [CrossRef]

4. Baba, A.; Tayfur, G. Ground water contamination and its effect on health in Turkey. Environ. Monit. Assess. 2011, 183, 77-94. [CrossRef] [PubMed]

5. Alemayehu, T. The impact of uncontrolledwaste disposal on surface water quality in Addis Ababa, Ethiopia. SINET Ethiop. J. Sci. 2004, 24, 93-104.

6. Spalding, R.F.; Exner, M.E. Occurrence of nitrate in ground water-A review. J. Environ. Qual. 1993, 22, 392-402. [CrossRef]

7. Zhang, W.L.; Tian, Z.X.; Zhang, N.; Li, X.Q. Nitrate pollution of ground water in northern China. Agriculture, Ecosyst. Environ. 1996, 59, 223-231. [CrossRef]

8. Gulis, G.; Czompolyova, M.; Cerhan, J.R. An ecologic study of nitrate in municipal drinking water and cancer incidence in Trnava District, Slovakia. Environ. Res. 2002, 88, 182-187. [CrossRef] [PubMed]

9. Maghanga, J.K.; Kituyi, J.L.; Kisinyo, P.O.; Ng'etich, W.K. Impact of Nitrogen Fertilizer Applications on Surface Water Nitrate Levels within a Kenyan Tea Plantation. J. Chem. 2013, 2013, 196516. [CrossRef]

10. Del Nero, Z.A. Deep Soil Nitrogen Survey, Lower Umatilla Basin, Oregon. Master's Thesis, Oregon State University, Bend, OR, USA, 1994.

11. Fadiran, A.; Mamba, S. Analysis of nitrates and nitrites in some water and factory effluent samples from some cities in Swaziland. Bull. Chem. Soc. Ethiop. 2005, 19, 35-44.

12. Mahler, R.L.; Smolen, M.D.; Borisova, T.; Boellstorff, D.E.; Adams, D.C.; Sochacka, N.W. The national water survey needs assessment program. Nat. Sci. Educ. 2013, 42, 98-103. [CrossRef]

13. Follett, R.; Walker, D.; Folle, R. Ground Water Quality Concerns about Nitrogen. In Nitrogen Management and Ground Water Protection; Elsevier: New York, NY, USA, 1989; pp. 1-22. 
14. Aldrich, S.R. Nitrogen management to minimize adverse effects on the environment. In Nitrogen in Crop Production; American Society of Agronomy, Crop Science Society of America, Soil Science Society of America: Madison, WI, USA, 1984; pp. 663-673.

15. Fraser, P. Health aspects of nitrate in drinking water. Sci. Total Environ. 1981, 12, 103-116. [CrossRef]

16. Jaffe, A.B.; Peterson, S.R.; Portney, P.R.; Stavins, R.N. Environmental regulation and the competitiveness of US manufacturing: What does the evidence tell us? J. Econ. Lit. 1995, 33, 132-163.

17. Keeney, D.R. Nitrogen management for maximum efficiency and minimum pollution. In Nitrogen in Agricultural Soils, Agronomy Monograph 22; Stevenson, F.J., Ed.; American Society of Agronomy, Crop Science Society of America, Soil Science Society of America: Madison, WI, USA, 1982; pp. 605-649.

18. Nwobodo, T.N.; Anikwe, M.A.N.; Chukwu, K.E. Assessment of spatio-temporal variation of ground water quality in Udi-Ezeagu watershed, Enugu Area, Southeastern Nigeria. Int. J. Environ. Monit. Anal. 2015, 3, 210-217. [CrossRef]

19. Hu, K.; Huang, Y.; Li, H.; Li, B.; Chen, D.; White, R.E. Spatial variability of shallow ground water level, electrical conductivity and nitrate concentration, and risk assessment of nitrate contamination in North China Plain. Environ. Int. 2005, 31, 896-903. [CrossRef] [PubMed]

20. Ju, X.T.; Kou, C.L.; Zhang, F.S.; Christie, P. Nitrogen balance and ground water nitrate contamination: Comparison among three intensive cropping systems on the North China Plain. Environ. Pollut. 2006, 143, 117-125. [CrossRef] [PubMed]

21. Capone, D.G.; Bautista, M.F. A ground water source of nitrate in nearshore marine sediments. Nature 1985, 313, 214. [CrossRef]

22. Johnson, C.J.; Kross, B.C. Continuing importance of nitrate contamination of ground water and wells in rural areas. Am. J. In. Med. 1990, 18, 449-456.

23. Gourley, M.; Vomocil, M.; Newton, M. Forest weeding reduces the effect of deer-browsing on Douglas fir. For. Ecol. Manag. 1990, 36, 177-185. [CrossRef]

24. Hill, M.J. Nitrates and Nitrites in Food and Water; Woodhead Publishing: Cambridge, UK, 1996.

25. Burkart, M.R.; Kolpin, D.W. Hydrologic and land-use factors associated with herbicides and nitrate in near-surface aquifers. J. Environ. Qual. 1993, 22, 646-656. [CrossRef]

26. Pionke, H.; Sharma, M.; Hirschberg, K.-J. Impact of Irrigated horticulture on nitrate concentrations in ground water. Agric. Ecosyst. Environ. 1990, 32, 119-132. [CrossRef]

27. European Environment Agency (EEA). Present Concentration of Nitrate in Ground Water Bodies in European Countries; European Environment Agency (EEA): Copenhagen, Denmark, 2003.

28. Fried, J.J. Nitrates and Their Control in the EEC Aquatic Environment. In Nitrate Contamination; Springer: Berlin, Germany, 1991; pp. 3-11.

29. Withers, P.J.; Lord, E.I. Agricultural nutrient inputs to rivers and ground waters in the UK: Policy, environmental management and research needs. Sci. Total Environ. 2002, 282, 9-24. [CrossRef]

30. Macgregor, C.J.; Warren, C.R. Adopting sustainable farm management practices within a Nitrate Vulnerable Zone in Scotland: The view from the farm. Agric. Ecosyst. Environ. 2006, 113, 108-119. [CrossRef]

31. Ziblim, S.-D. Assessing Human Activities and Their Effects on Water Quality: The Case of Bulpeila Dam in the Tamale Metropolis of Northern Region of Ghana. J. Environ. Earth Sci. 2013, 3, 32-39.

32. Convey, P. Fertilizer Risks in the Developing Countries: A Review; International Institute for Environment and Development: London, UK, 1988.

33. Dagnew, T.; Assefa, D.; Woldemariam, G.; Solomon, F.; Schmoll, O. Rapid Assessment of Drinking-Water Quality in the Federal Republic of Ethiopia; Country Report; Federal Democratic Republic of Ethiopia, Ministry of Health, Environmental Health Department: Addis Ababa, Ethiopia, 2007; pp. 19-67.

34. Beyene, A.; Addis, T.; Kifle, D.; Legesse, W.; Kloos, H.; Triest, L. Comparative study of diatoms and macroinvertebrates as indicators of severe water pollution: Case study of the Kebena and Akaki rivers in Addis Ababa, Ethiopia. Ecol. Indic. 2009, 9, 381-392. [CrossRef]

35. Duguma, B.; Tegegne, A.; Hegde, B.P. Assessment of the effect of season and location on microbiological and physicochemical quality of livestock drinking water in Ginchi watershed, Ethiopia. Glob. Vet. 2012, 8, 342-346.

36. Akale, A.T.; Dagnew, D.C.; Giri, S.; Belete, M.A.; Tilahun, S.A.; Mekuria, W.; Steenhuis, T.S. Ground water Quality in an Upland Agricultural Watershed in the Sub-Humid Ethiopian Highlands. J. Water Resour. Prot. 2017, 9, 1199-1212. [CrossRef] 
37. Shiferaw, B.; Holden, S. Soil erosion and smallholders' conservation decisions in the highlands of Ethiopia. World Dev. 1999, 27, 739-752. [CrossRef]

38. Teklu, E.; Hailemariam, T. Agronomic and economic efficiency of manure and urea fertilizers use on vertisols in ethiopian highlands. Agric. Sci. China 2009, 8, 352-360. [CrossRef]

39. Amhara Design and Supervision Works Enterprise (ADSWE). Soil Map of Amhara Region, Land Use and Administration Work Process; Amhara Design and Supervision Works Enterprise (ADSWE): Bahir Dar, Ethiopia, 2012.

40. Tebebu, T.Y.; Steenhuis, T.S.; Dagnew, D.C.; Guzman, C.D.; Bayabil, H.K.; Zegeye, A.D.; Collick, A.S.; Langan, S.; McAllister, C.; Langendoen, E.J.; et al. Improving efficacy of landscape interventions in the (sub) humid Ethiopian highlands by improved understanding of runoff processes. Front. Earth Sci. 2015, 3, 49.

41. Bazezew, A.; Bewket, W.; Nicolau, M. Rural household's livelihood assets, strategies and outcomes in drought-prone areas of the Amhara Region, Ethiopia: Case Study in Lay Gaint District. Afr. J. Agric. Res. 2013, 8, 5716-5727.

42. Madison, R.J.; Brunett, J.D. Overview of the occurrence if nitrate in ground water of the United States. In National Water Summary 1984: Hydrologic Events, Selected Water Ouality Trends and Ground-Water Resources; Water Supply Paper 2275; U.S. Geological Survey: Reston, VA, USA, 1984; pp. 93-103.

43. Berndt, M.P.; Katz, B.G.; Lindsey, B.D.; Ardis, A.F.; Skach, K.A. Comparison of water chemistry in spring and well samples from selected carbonate aquifers in the United States. In Proceedings of the U.S. Geological Survey Karst Interest Group, Rapid City, SD, USA, 12-15 September 2005; pp. 74-81.

44. Flores-López, F.; Easton, Z.M.; Steenhuis, T.S. Relative Effects of Ground water and Near Stream Best Management Practices on Soluble Reactive Phosphorus and Nitrate Surface Water Concentrations on a Dairy Farm in a Catskill Mountain Valley. J. Soil Water Conserv. 2010, 65, 438-449. [CrossRef]

45. Heffernan, J.B.; Albertin, A.R.; Fork, M.L.; Katz, B.G.; Cohen, M.J. Denitrification and inference of nitrogen sources in the karstic Floridan Aquifer. Biogeosciences 2012, 9, 1671-1690. [CrossRef]

46. Chand, S.; Ashif, M.; Zargar, M.Y.; Ayub, B.M. Nitrate Pollution: A Menace to Human, Soil, Water and Plant. Univers. J. Environ. Res. Technol. 2011, 1, 22-32.

47. Hallberg, G.R.; Keeney, D.R. Nitrate, Regional Ground-Water Quality; Alley, W.J., Ed.; Van Nostrand Reinhold: New York, NY, USA, 1993; pp. 297-322.

48. Bayabil, H.K.; Tilahun, S.A.; Collick, A.S.; Yitaferu, B.; Steenhuis, T.S. Are runoff processes ecologically or topographically driven in the (sub) humid Ethiopian highlands? The case of the Maybar watershed. Ecohydrology 2010, 3, 457-466. [CrossRef]

49. Bouchard, D.C.; Williams, M.K.; Surampalli, R.Y. Nitrate contamination of ground water: Sources and potential health effects. J.-Am. Water Works Assoc. 1992, 84, 85-90. [CrossRef]

50. Baker, M.A.; Vervier, P. Hydrological variability, organic matter supply and denitrification in the Garonne River ecosystem. Freshw. Biol. 2004, 49, 181-190. [CrossRef] 